\title{
SINTESIS KOMPOSIT KITOSAN/MgO/Ag DAN ANALISIS EFEKTIVITASNYA SEBAGAI ANTIBAKTERI
}

\author{
Shintya Maryani ${ }^{1}$, Henry F. Aritonang ${ }^{1}$, Vanda S. Kamu ${ }^{1}$ \\ ${ }^{1}$ Program Studi Kimia Fakultas Matematika dan Ilmu Pengetahuan Alam Universitas Sam Ratulangi \\ Email: henryaritonang@unsrat.ac.id
}

\begin{abstract}
ABSTRAK
Penelitian tentang sintesis komposit kitosan/MgO/Ag dengan variasi massa prekursor $\mathrm{AgNO}_{3} 0,05 \mathrm{~g}, 0,1 \mathrm{~g}, 0,15$ $\mathrm{g}$ dan $0,2 \mathrm{~g}$ disintesis dengan metode kopresipitasi. Komposit yang dihasilkan dikarakterisasi menggunakan $X$ Ray Diffractometry (XRD) dan Scanning Electron Microscope (SEM). Selanjutnya, keefektifan komposit ini sebagai antibakteri diuji yaitu Staphylococcus aureus (Gram positif) dan Escherichia coli (Gram negatif). Hasil penelitian menunjukkan bahwa puncak karakteristik partikel $\mathrm{MgO}$ dan Ag tidak muncul pada difraktogram XRD, tetapi secara visual dan morfologis SEM mendukung pembentukan dua partikel dan berdasarkan literatur dari hasil peneliti lain. Selain itu, komposit ini efektif dalam menghambat pertumbuhan kedua bakteri.
\end{abstract}

Kata kunci: komposit, kitosan, $\mathrm{MgO}, \mathrm{Ag}$, antibakteri.

\begin{abstract}
Research on the synthesis of chitosan/MgO/Ag composites with variations in the mass of $\mathrm{AgNO}_{3}$ precursors 0.05 $\mathrm{g}, 0.1 \mathrm{~g}, 0.15 \mathrm{~g}$ and $0.2 \mathrm{~g}$ were synthesized by the coprecipitation method. The resulting composites were characterized using X-Ray Diffractometry (XRD) and Scanning Electron Microscope (SEM). Furthermore, the effectiveness of this composite as an antibacterial was tested, namely Staphylococcus aureus (Gram positive) and Escherichia coli (Gram negative). The results showed that the characteristic peaks of $\mathrm{MgO}$ and Ag particles did not appear on the XRD diffractogram, but visually and morphologically SEM supported the formation of two particles and based on the literature from the results of other researchers. In addition, this composite is effective in inhibiting the growth of both bacteria.
\end{abstract}

Keywords: composite, chitosan, MgO, Ag, antibacterial.

\section{PENDAHULUAN}

Nanoteknologi merupakan pengetahuan dan kontrol material pada skala nano dalam dimensi antara 1-100 nanometer. Ukuran partikel yang sangat kecil tersebut dimanfaatkan untuk mendesain dan menyusun atau memanipulasi material sehingga dihasilkan material dengan sifat dan fungsi baru. Nanoteknologi merupakan fenomena unik yang dapat diaplikasikan dalam bidang teknologi informasi, farmasi dan kesehatan, pertanian, industri, dan lain-lain (Clunan, 2014). Nanopartikel merupakan suatu partikel yang berukuran sekitar $<100 \mathrm{~nm}$ dengan bentuk dan diameter yang bervariasi. Pada skala ini, atomatom partikel pada permukaan memberikan sifat yang unik (Sun dkk., 2013). Karena sifatnya yang unik, nanopartikel pun banyak diteliti (Xia dkk, 2011). Perkembangan nanoteknologi sendiri tidak terlepas dari riset mengenai material nano karena material berukuran nano memiliki sejumlah sifat fisika dan kimia yang lebih unggul dibandingkan material berukuran besar (bulk) (Ahmed dkk., 2004). Nanopartikel memiliki banyak kegunaan antara lain sebagai sensor, katalis, zat pelapis permukaan, dan antibakteri (Ristian, 2013).

Untuk mensintesis nanopartikel tersebut terdapat beberapa metode, antara lain: kopresipitasi, sintesis hidrotermal, metode prekursor sitrat, metode keramik-gelas (glass ceramic) dan proses sol-gel (Costa, 2003). Selain itu, beberapa peneliti menggunakan polimer alam sebagai penstabil partikel untuk mendapatkan partikel berukuran nano, seperti nata de coco (Yang dkk., 2014), kitosan (Ilyina dkk., 2000), dan senyawa-senyawa metabolit sekunder yang terdapat pada tanaman ( Hwang dkk., 2000).

Akmaz dkk. (2013) dan Dananjaya dkk. (2014) telah menggunakan kitosan sebagai 
penstabil partikel perak $(\mathrm{Ag})$ dalam mensintesis material komposit kitosan/nanopartikel $\mathrm{Ag}$ dengan metode kopresipitasi. Hasil penelitian tersebut menunjukkan bahwa komposit ini menunjukkan efektivitasnya sebagai antibakteri, baik bakteri gram negatif maupun positif. Sementara itu, Riyadh dkk. (2018) menggunakan kitosan sebagai penstabil nanopartikel magnesium oksida $(\mathrm{MgO})$ dalam mensintesis nanopartikel kitosan/ $\mathrm{MgO}$ dan digunakan sebagai katalis untuk mensintesis tiazol dan $[1,3,4]$ tiadiazol. Demikian pula peneliti Almerindo dkk. (2011) juga telah menggunakan kitosan dalam mensintesis nanopartikel kitosan/MgO, namun komposit tersebut digunakan sebagai katalis untuk transesterifikasi minyak kedelai. Menurut beberapa peneliti, $\mathrm{MgO}$ menunjukkan efektivitasnya sebagai antibakteri, baik bakteri gram negatif maupun positif (Nguyen dkk., 2018; Noori \& Kareem, 2019; He dkk., 2016). Selain nanopartikel $\mathrm{MgO}$ dalam bentuk tunggalnya, nanokomposit $\mathrm{MgO} / \mathrm{Ag}$ tersebut menunjukkan efektivitasnya sebagai antibakteri (Ayinde dkk., 2018).

Berdasarkan hasil penelitian yang telah dilaporkan tersebut, nanokomposit $\mathrm{MgO}-\mathrm{Ag}$ berpotensi sebagai antibakteri. Oleh karena itu, peneliti mencoba untuk mensintesis komposit kitosan/nanopartikel MgO-Ag karena hingga kini, komposit kitosan/nanopartikel $\mathrm{MgO}-\mathrm{Ag}$ belum ada dilaporkan. Komposit yang dihasilkan akan dianalisis efektivitasnya sebagai antibakteri, baik gram negatif, bakteri Escherichia coli maupun positif, Staphylococcus aureus. Komposit yang dihasilkan akan dianalisis dengan X-Ray Diffractometry (XRD) dan Scanning Electron Microscope (SEM) seperti pada beberapa penelitian yang telah mensintesis material-material nano (San dkk, 2015; Rashada dkk., 2008). Digunakannya kitosan dalam penelitian ini karena kitosan dapat digunakan sebagai matrik dan sifatnya yang memiliki daya serap air yang tinggi, tidak beracun, dan dapat terbiodegradasi (Croisier \& Jerome, 2013). Kitosan adalah biopolimer polisakarida dengan biokompatibilitas yang sangat baik, mudah terurai secara alami dan toksisitasnya rendah (Praveenkumar dkk., 2014; Mat Zain dkk., 2014). Tujuan untuk mensintesis komposit kitosan/MgO/Ag dan untuk membuktikan efektivitas antibakteri dari komposit kitosan/Mgo/Ag terhadap bakteri Escherichia coli dan Staphylococcus aureus.

\section{BAHAN DAN METODE}

Bahan yang digunakan adalah kitosan, magnesium nitrat heksahidrat, perak nitrat, natrium hidroksida, metanol, asam asetat diperoleh dari Merck (Damstadt), sedangkan nutrient agar (NA), tablet cyprofloxasin, bakteri Staphylococcus aureus dan Escherichia coli, larutan Mc. Farland diperoleh dari Laboratorium Mikrobiologi, Farmasi FMIPA Unsrat.

\section{Sintesis komposit kitosan/MgO/Ag (Riyadh dkk., 2018)}

Komposit kitosan/MgO/Ag disintesis dengan metode ko-presipitasi menggunakan prekursor magnesium nitrat heksahidrat $\left(\mathrm{Mg}\left(\mathrm{NO}_{3}\right)_{2} \cdot 6 \mathrm{H}_{2} \mathrm{O}\right)$ dan perak nitrat $\left(\mathrm{AgNO}_{3}\right)$, masing-masing sebagai sumber nanopartikel $\mathrm{MgO}$ dan Ag. Mula-mula, sebanyak 2 g kitosan dilarutkan dalam $100 \mathrm{~mL}$ asam asetat $2 \%$ dan disonikasi selama 2 jam. Selanjutnya sebanyak 1 g $\left(\mathrm{Mg}\left(\mathrm{NO}_{3}\right)_{2} \cdot 6 \mathrm{H}_{2} \mathrm{O}\right)$ dan $0,05 \quad \mathrm{~g} \quad \mathrm{AgNO}_{3}$ dimasukkan ke dalam larutan kitosan yang telah disonikasi dan disonikasi kembali selama 2 jam. Selanjutnya, larutan ini dituangkan ke dalam cawan petri, dan selanjutnya larutan dikeringkan dan dimasukkan ke dalam oven pada suhu $60{ }^{\circ} \mathrm{C}$ selama 4 jam. Kemudian cawan petri beserta membran direndam dalam larutan $\mathrm{NaOH} \mathrm{0,2} \mathrm{M}$ selama 3 jam. Selanjutnya membran dilepas dan dikeringkan di dalam oven. Selanjutnya membran dilepas dalam cawan petri dan dicuci dengan metanol sebanyak $3 \mathrm{x}$ dan dikeringkan kembali ke dalam oven pada suhu $60{ }^{\circ} \mathrm{C}$ selama 2 jam. Komposit yang dihasilkan ini diberi kode komposit kitosan/MgO/Ag-0,05. Komposit yang telah kering dikarakterisasi dengan Scanning Electron Microscope (SEM), X-Ray Diffraction (XRD) dan dianalisis sifat antibakterinya. Dengan cara yang sama, dilakukan juga sintesis komposit kitosan/MgO dan kitosan/Ag.

\section{Karakterisasi komposit hasil sintesis $X$ - ray diffraction (XRD)}

Pola XRD (Rigaku SmartLab 3kV) dicatat pada difraktometer sinar-X (PW1710, Philips), menggunakan radiasi $\mathrm{Cu} \mathrm{K} \alpha(\lambda=0.154$ $056 \mathrm{~nm}$ ) pada $40 \mathrm{kV}$ dan $30 \mathrm{~mA}$. Sudut difraksi berkisar antara $10^{\circ}$ sampai $90^{\circ}$. Ukuran kristalit komposit kitosan/MgO/Ag dihitung berdasarkan pengukuran difraksi sinar-X. Ukuran kristalit dihitung dari lebar penuh pada setengah maksimum (full width half maximum, FWHM) 
puncaknya dengan menggunakan rumus Scherrer (Monshi dkk., 2012)

$$
L=\frac{k \lambda}{\beta \cos \theta},
$$

dimana $L$ adalah ukuran kristal rata-rata partikel $\mathrm{TiO}_{2} / \mathrm{Ag}, K$ adalah konstanta yang bernilai $0,9, \lambda$ adalah panjang gelombang sinar$\mathrm{X}, \beta$ adalah (FWHM) dalam radian, dan $\theta$ adalah sudut difraksi.

\section{Pembuatan media tumbuh dan sterilisasi alat}

Timbang nutrient agar (NA) 9,8 g kemudian dilarutkan dalam $350 \mathrm{~mL}$ akuades lalu dimasukkan dalam Erlenmeyer dan disterilkan dalam autoklaf pada suhu $121{ }^{\circ} \mathrm{C}$ selama 30 menit.

\section{Pembuatan larutan Mc Farland}

Sebanyak 0,5 mL BaCl 2 1,75\% (dibuat dengan cara melarutkan $1.75 \mathrm{~g} \mathrm{BaCl}_{2}$ ke dalam $100 \mathrm{~mL}$ akuades) ditambahkan dengan $9,5 \mathrm{~mL}$ $\mathrm{H}_{2} \mathrm{SO}_{4} \quad 1 \%$ (dibuat dengan cara $1 \mathrm{~mL} \mathrm{H}_{2} \mathrm{SO}_{4}$ pekat ditambahkan aquades sampai $100 \mathrm{~mL}$ ) sehingga volume larutan mencapai $10 \mathrm{~mL}$. Kemudian, larutan dipindahkan ke dalam tabung reaksi dan divortex dan dilihat kekeruhannya.

\section{Pembuatan bakteri uji}

Bakteri diencerkan dengan mencampurkan masing-masing 1 ose suspensi bakteri Staphylococcus aureus dan Escherichia coli ke dalam tabung reaksi yang telah berisi 5 $\mathrm{mL}$ larutan $\mathrm{NaCl} \quad 0,9 \quad \%$. Kemudian dihomogenkan menggunakan vortex dan kekeruhannya dibandingkan dengan kekeruhan 0,5 Mc Farland hingga kekeruhan larutan bakteri harus sama dengan kekeruhan larutan $0,5 \mathrm{Mc}$ Farland. Jika kekeruhan larutan belum sama, maka ke dalam larutan bakteri ditambahkan lagi 1 ose suspensi bakteri hingga kekeruhan larutan bakteri sama dengan kekeruhan larutan $0,5 \mathrm{Mc}$ Farland, sehingga jumlah bakteri memenuhi standarisasi untuk uji kepekaan yaitu: $10^{5}$ $10^{8} / \mathrm{ml}$.

\section{Daya hambat bakteri}

Dimasukkan sebanyak $20 \mathrm{~mL}$ larutan Nutrient Agar ke dalam cawan petri kemudian didiamkan selama 15 menit sampai larutan Nutrient Agar mengeras. Kemudian sebanyak $0,1 \mathrm{~mL}$ larutan bakteri yang telah distandarisasi tadi, dioleskan pada media tumbuh Nutrient Agar. Setelah itu, diletakkan kontrol negatif, kontrol positif, dan sampel yang telah disiapkan (2 ulangan). Media yang telah dibuat, diinkubasi ke dalam inkubator dengan suhu $37{ }^{\circ} \mathrm{C}$ selama 24 jam, dan diukur pada keesokan harinya dengan diameter zona bening (clear zone) yang terbentuk dengan menggunakan jangka sorong (Eko, 2013)

\section{HASIL DAN PEMBAHASAN}

\section{Sintesis komposit kitosan/MgO/Ag}

Pembuatan membran komposit kitosan $/ \mathrm{MgO} / \mathrm{Ag}$ dilakukan dengan cara melarutkan serbuk kitosan ke dalam larutan 100 $\mathrm{mL}$ asam asetat $2 \%$. Selanjutnya, magnesium nitrat heksahidrat $\left(\mathrm{Mg}\left(\mathrm{NO}_{3}\right)_{2} \cdot 6 \mathrm{H}_{2} \mathrm{O}\right)$ dan perak nitrat $\left(\mathrm{AgNO}_{3}\right)$ dimasukkan ke dalam larutan kitosan. Larutan ini disonikasi agar ion-ion logam maupun oksida logam terdistribusi dengan baik pada semua bagian dari kitosan. Selanjutnya, larutan ini dituangkan pada cawan petri dan dikeringkan agar membentuk membran. Membran yang terbentuk direndam di dalam larutan $\mathrm{NaOH} \quad 0,2 \mathrm{M}$ agar proses presipitasi terjadi sehingga partikel $\mathrm{MgO}$ dan $\mathrm{Ag}$ terbentuk dan terdeposisi di dalam kitosan. Proses pengeringan membran komposit ini di dalam oven dilanjutkan agar kristal $\mathrm{MgO}$ dan Ag benar-benar terbentuk. Terdeposisinya partikel $\mathrm{MgO}$ dan $\mathrm{Ag}$ dapat diketahui dari perubahan warna membran kitosan sebelum dan setelah deposisi. Untuk melihat perbedaan visual dari membran komposit tersebut, maka sintesis komposit dari masing-masing kitosan, $\mathrm{MgO}$ dan $\mathrm{Ag}$ juga dilakukan. Adapun perbedaan visual komposit tersebut disajikan pada Gambar 1 berikut. 


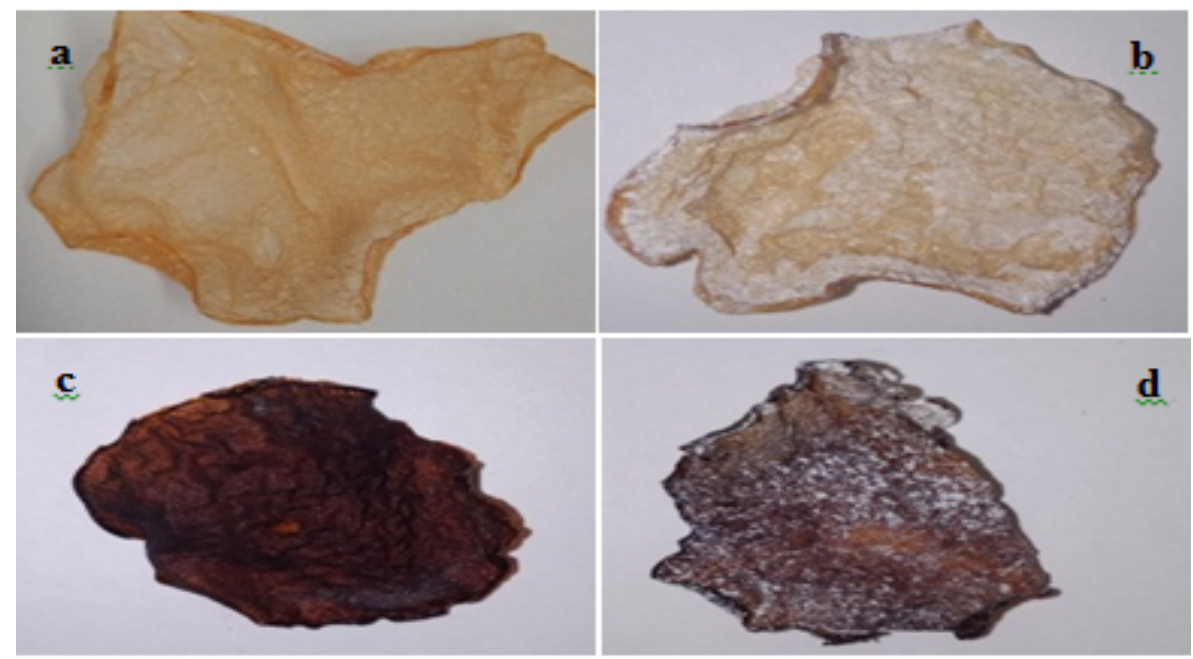

Gambar 1. Perbedaan morfologi membran kitosan sebelum dan setelah deposisi, (a) komposit membran kitosan (b) kitosan/MgO (c) kitosan/Ag, (d) kitosan/MgO/Ag-0,2.

\section{Karakterisasi dengan X-ray diffractrometry} (XRD)

Pengujian XRD dilakukan untuk mengetahui telah terbentuknya partikel-partikel $\mathrm{MgO}$ dan Ag dari sumber prekursornya. Pada difraktogramnya akan muncul pola difraksi dengan adanya puncak-puncak pada daerah $2 \theta$ yang karakteristik dengan partikel tersebut, seperti yang tersaji pada Gambar 2 berikut.
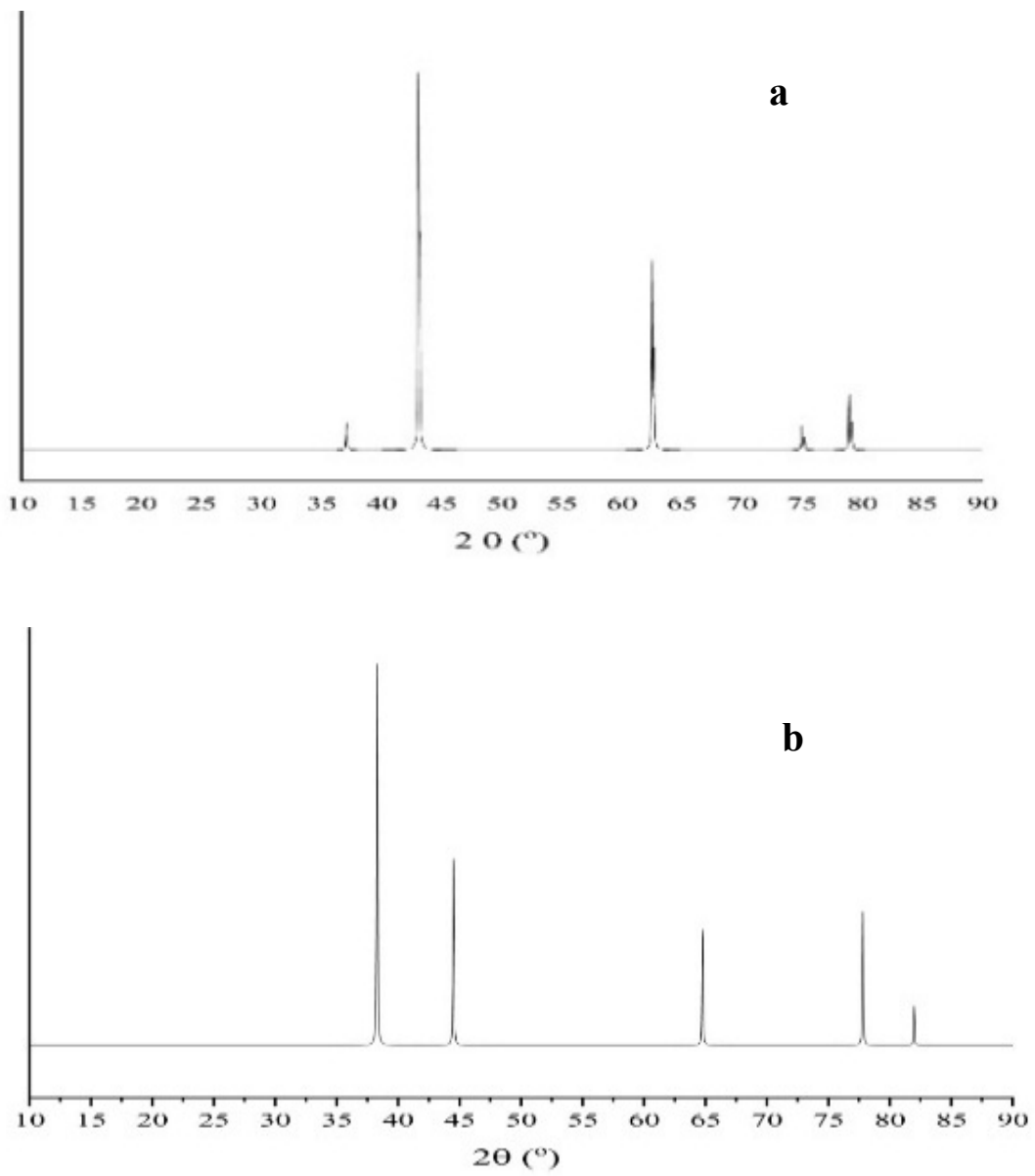

Gambar 2. Difraktogram (a) standar MgO dan (b) standar Ag 
Pola difraksi sampel membran nanokomposit telah dibandingkan dengan pola difraksi standar untuk partikel-partikel $\mathrm{MgO}$ dan Ag. Dalam penelitian ini, sebagai pembanding menggunakan standar dari Inorganic Crystal Structur Database (ICSD). Berdasarkan data dari ICSD tersebut, puncak-puncak karakteristik dari $\mathrm{MgO}$ berada pada daerah $2 \theta$ sebesar $37,08^{\circ}$; $43,08^{\circ} ; 62,52^{\circ} ; 62,54^{\circ} ; 74,98^{\circ} ; 75^{\circ}$. Sementara itu, Ag berada pada daerah $2 \theta$ sebesar $38,08^{\circ}$; 38,$28 ; \quad 44,56^{\circ} ; \quad 64,67^{\circ} ; \quad 77,72^{\circ} ; \quad 77,8^{\circ}$.
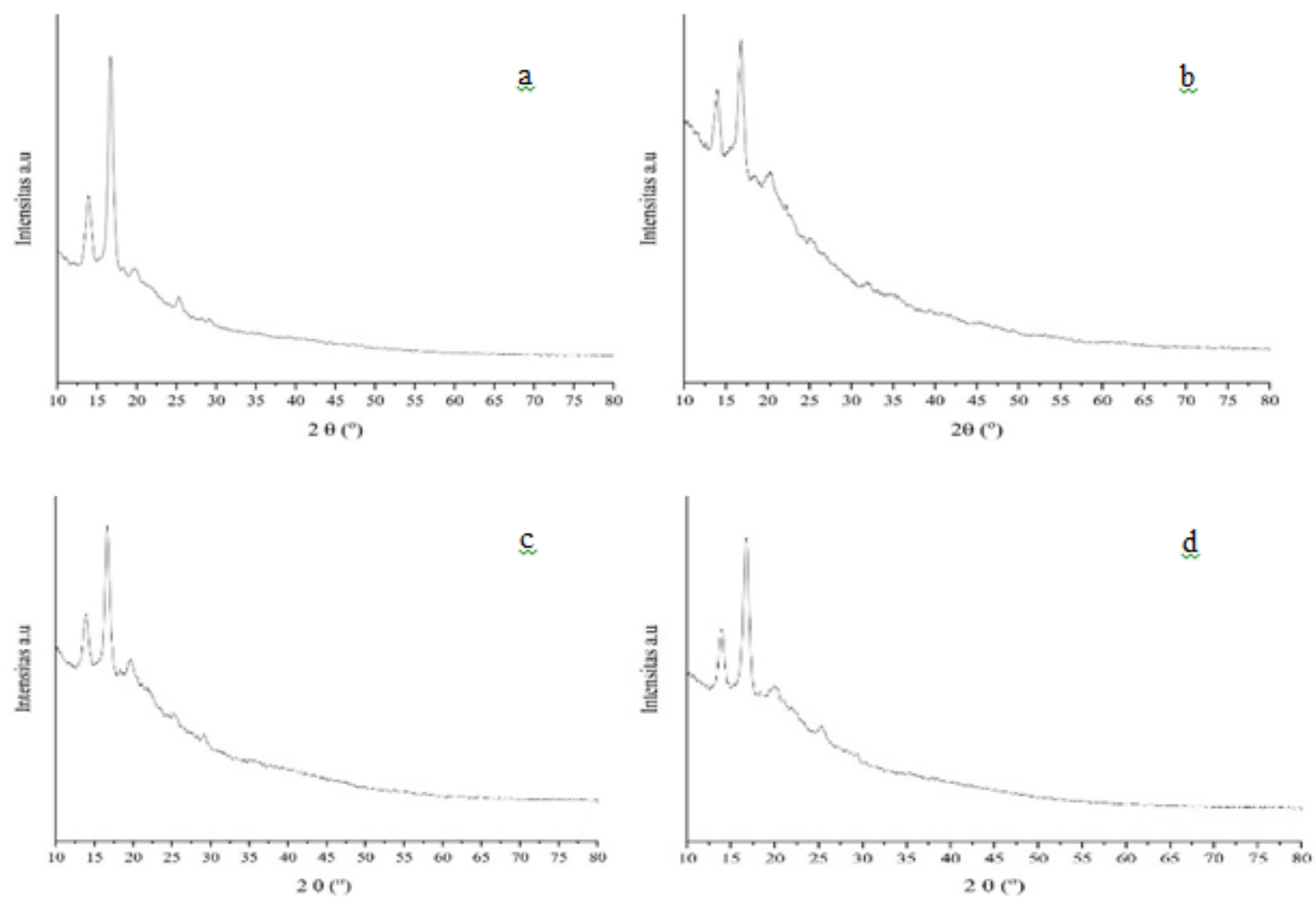

Gambar 3. Difraktogram sampel komposit kitosan/MgO/Ag- 0,05

(a) kitosan (b) kitosan $/ \mathrm{MgO}$ (c) kitosan $/ \mathrm{Ag}$

Berdasarkan difraktogram tersbut puncakpuncak daerah $2 \theta$ sampel kitosan muncul puncak kitosan berada pada daerah $2 \theta=13^{\circ}$, dan $18^{\circ}$. Kitosan $/ \mathrm{MgO}$ yaitu $14,02^{\circ} ; 16,8^{\circ} ; 20,3^{\circ}$; $25,0^{\circ}$. Sedangkan untuk kitosan $/ \mathrm{Ag}$ yaitu $13,9^{\circ}$; $16,6^{\circ} ; 18,3^{\circ} ; 19,6^{\circ} ; 25,4^{\circ} ; 29,2^{\circ}$. Selanjutnya untuk kitosan $/ \mathrm{MgO} / \mathrm{Ag}-0,05$ berada pada posisi puncak $2 \theta$ yaitu $13,9^{\circ} ; 16,7^{\circ} ; 19,8^{\circ} ; 25,3^{\circ}$. 
Tabel 1. Perbandingan daerah $2 \theta$

\begin{tabular}{|c|c|c|c|c|c|c|c|c|}
\hline \multirow[b]{2}{*}{$\begin{array}{c}\mathrm{MgO} \\
\text { (Standar) } \\
2 \theta\left(^{\circ}\right)\end{array}$} & \multirow[b]{2}{*}{$\begin{array}{c}\mathrm{Ag} \\
(\text { Standar }) \\
2 \theta\left({ }^{\circ}\right)\end{array}$} & \multicolumn{7}{|c|}{ Sampel } \\
\hline & & $\begin{array}{c}\text { kitosan } \\
2 \theta\left({ }^{\circ}\right)\end{array}$ & $\begin{array}{l}\text { kitosan/ } \\
\mathrm{MgO} \\
2 \theta\left(^{\circ}\right)\end{array}$ & $\begin{array}{c}\text { kitosan/ } \\
\mathrm{MgO} / \mathrm{Ag} \\
-0,05 \\
2 \theta\left(^{\circ}\right)\end{array}$ & $\begin{array}{c}\text { kitosan/ } \\
\mathrm{MgO} / \mathrm{Ag} \\
-0,10 \\
2 \theta\left(^{\circ}\right)\end{array}$ & $\begin{array}{c}\text { kitosan/ } \\
\mathrm{MgO} / \mathrm{Ag} \\
-0,15 \\
2 \theta\left(^{\circ}\right)\end{array}$ & $\begin{array}{c}\text { kitosan/ } \\
\mathrm{MgO} / \mathrm{Ag} \\
-0,2 \\
2 \theta\left(^{\circ}\right) \\
\end{array}$ & $\begin{array}{c}\text { kitosan/ } \\
\text { Ag } \\
-0,05 \\
2 \theta\left(^{\circ}\right) \\
\end{array}$ \\
\hline 37.08 & 38.08 & 13.9 & 14.02 & 13.9 & 13.9 & 13.9 & 14.0 & 13.9 \\
\hline 43.08 & 38.28 & 16.7 & 16.8 & 16.7 & 16.7 & 16.7 & 16.8 & 16.6 \\
\hline 62.52 & 44.56 & 18.3 & 20.3 & 19.8 & 18.4 & 25.4 & 25.3 & 18.3 \\
\hline 62.54 & 64.67 & 19.8 & 25.0 & 25.3 & 19.8 & & & 19.6 \\
\hline $\begin{array}{c}74.98 \\
75\end{array}$ & 77.72 & 25.4 & & 29.1 & 25.3 & & & 25.4 \\
\hline
\end{tabular}

Berdasarkan Tabel 1, hasil pengukuran diameter zona hambat pada bakteri Escherichia coli dan Staphylococcus aureus diperoleh daya hambat bakteri terhadap bakteri Escherichia coli dan Staphylococcus aureus memiliki hasil yang berbeda pada setiap konsentrasinya. Uji aktivitas antibakteri diawali dengan bakteri E.coli terhadap komposit. Ketika membran komposit kitosan $/ \mathrm{MgO}$ digunakan tidak menghasilkan daya hambat. Sementara itu, ketika membran komposit kitosan/Ag digunakan, daya hambat rata-rata yang dihasilkan sebesar $4,12 \mathrm{~mm}$. Ini menunjukkan bahwa nanopartikel Ag lebih efektif dalam menghambat pertumbuhan sel bakteri. Bila membran komposit kitosan/MgO/Ag dengan variasi konsentrasi $\mathrm{Ag}$ yang berbeda maka daya hambat pertumbuhan bakteri yang dihasilkan juga berbeda-beda. Menggunakan membran komposit kitosan $/ \mathrm{MgO} / \mathrm{Ag}-0,05$, daya hambat yang dihasilkan lebih rendah dan akan terus naik daya hambatnya hingga konsentrasi kitosan/MgO/Ag0,1 . Daya hambat naik karena konsentrasi $\mathrm{Ag}$ yang lebih tinggi. Namun ketika membran komposit kitosan/Ag-0,05 ternyata daya hambatnya relatif lebih rendah dibandingkan dengan komposit kitosan/MgO/Ag-0,2 . Ini menunjukkan bahwa nanopartikel $\mathrm{MgO}$ memberikan sumbangan dalam menghambat pertumbuhan bakteri. Selain itu, informasi ini menunjukkan bahwa komposit kitosan/ $\mathrm{MgO} / \mathrm{Ag}$ lebih efektif dalam menghambat pertumbuhan bakteri E.coli dibanding komposit kitosan $/ \mathrm{MgO}$ dan komposit kitosan/Ag.
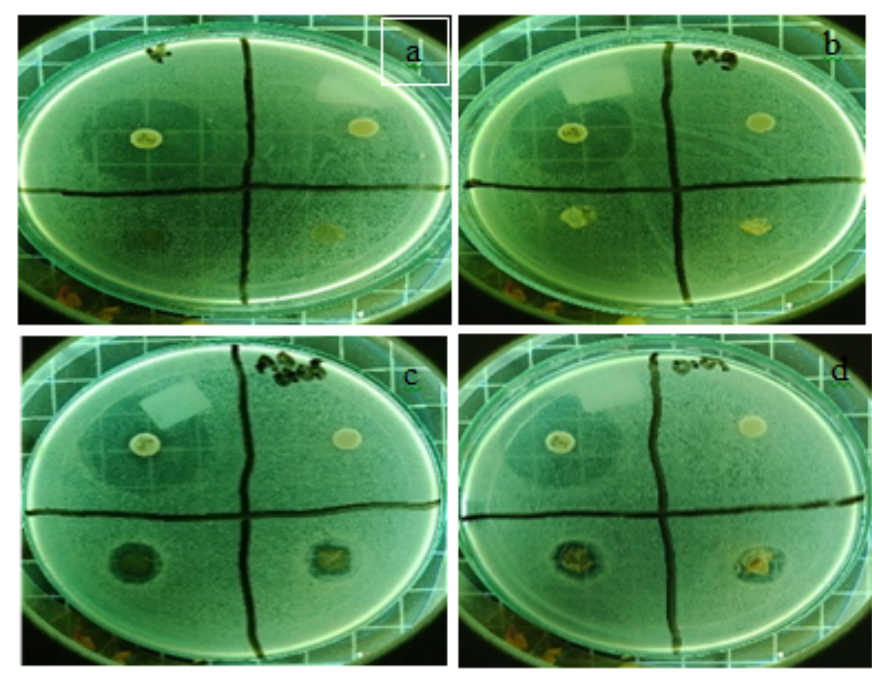

Gambar 4. Hasil uji aktivitas antibakteri terhadap bakteri gram negatif (Escherichia coli). (a) kitosan (b) kitosan/MgO (c) kitosan/Ag (d) kitosan/MgO/Ag-0,05

Selanjutnya uji aktivitas antibakteri
membran komposit dengan bakteri Staphylococcus aureus menunjukkan pola yang mirip dengan menggunakan uji terhadap bakteri Escherichia coli. Ketika menggunakan membran komposit kitosan/MgO, tidak menghasilkan daya hambat bakteri, seperti halnya saat diuji pada bakteri Escherichia coli. 
Bila menggunakan membran komposit kitosan/Ag daya hambat rata-ratanya sebesar 6,125 mm. Selanjutnya, bila menggunakan membran komposit kitosan/MgO/Ag-0,05 dan komposit kitosan/MgO/Ag-0,1, daya hambat relatif lebih rendah dibanding menggunakan komposit kitosan/Ag. Namun, ketika konsentrasi Ag ditingkatkan, yaitu pada komposit kitosan/MgO/Ag-0,15 dan komposit kitosan/MgO/Ag-0,2, daya hambatnya relatif meningkat. Informasi ini menunjukkan bahwa komposit kitosan/MgO/Ag lebih efektif dalam menghambat pertumbuhan bakteri Staphylococcus aureus yaitu pada penambahan massa prekursor Ag sebesar 0,15 g dan 0,2 g. Bila dibandingkan dengan hasil uji sampel terhadap kedua jenis bakteri ini menunjukkan bahwa semua sampel komposit kitosan/MgO/Ag menghasilkan zona bening yang relatif lebih lebar pada uji dengan bakteri Escherichia coli dibading zona bening yang dihasilkan pada uji dengan bakteri Staphylococcus aureus. Informasi ini menunjukkan bahwa komposit kitosan $/ \mathrm{MgO} / \mathrm{Ag}$ relatif lebih efektif dalam menghambat pertumbuhan bakteri Escherichia coli dibanding terhadap bakteri Staphylococcus aureus.

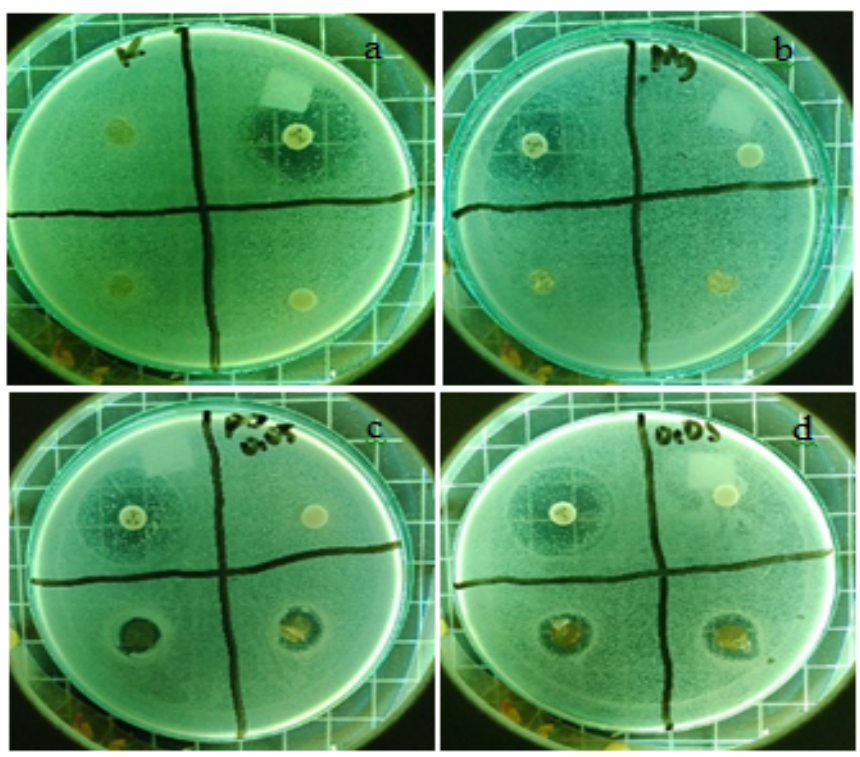

Gambar 5. Hasil uji aktivitas antibakteri terhadap bakteri gram positif (Staphylococcus aureus). (a) kitosan (b) kitosan/MgO (c) kitosan/Ag (d) kitosan/MgO/Ag-0,05

\section{KESIMPULAN}

Komposit kitosan $/ \mathrm{MgO} / \mathrm{Ag}$ relatif lebih efektif dalam menghambat pertumbuhan bakteri Escherichia coli daripada bakteri Staphylococcus aureus karena dilihat dari zona bening yang terbentuk bahwa bakteri Escherichia coli daya hambatnya lebih besar.

\section{DAFTAR PUSTAKA}

Ahmed, A., Akkamwar, B., Sastry, M., Rai, A., Singh, A. \& Shankar, S.S. 2004. biological synthesis of triangular gold nanoprism. Journal of Nature. 3(7), 482-491.

Akmaz. S., Esra, D.A., Muzaffer, Y. \& Erguven, O. 2013. The effect of ag content of the chitosan-silver nanoparticle composite material on the structure and antibacterial activity. Advances in Materials Science and Engineering. 2013(3), 1-6.

Almerindo, F.D., Gizelle, I., Probst, E.M., Campos, R.M., Almeida, Simoni, M.P., Meneghetti, M.R., Meneghetti, J.M. \& Humberto V.F. 2011. Magnesium oxide prepared via metal-chitosan complexation method: Application as catalyst for transesterification of soybean oil and catalyst deactivation studies. Journal of Power Sources. 196(19), 8057-8063.

Arass, J.N. \& Fadil, A.K. 2019. The effect of magnesium oxide nanoparticles on the antibacterial and antibiofilm properties of glass-ionomer cement. Heliyon. 5(10), 2568. 
Ayinde, M.W., Wasiu, B., Gitari, M.M. \& Amidou, S. 2018. Biosynthesis of ultrasonically modified Ag-Mgo nanocomposite and its potential for antimicrobial Activity. Journal of Nanotechnology. 2018(3), 10-23.

Costa A.C.F.M., Tortellab, E., Morellib, M.R. \& Kiminamib, R.H.G. 2003. Synthesis, microstructure and magnetic properties of $\mathrm{Ni}-\mathrm{Zn}$ ferrites. Journal of Magnetism and Magnetic Materials. 256(1-3), 174182.

Dananjaya, S.H., Godahewa, G.I., Jayasooriya, R., Chulhong, O.H., Jehee, L. \& Mahanama, D.Z. 2014. Chitosan silver nano composites (CAgNCs) as potential antibacterial agent to control Vibrio tapetis. Journal Veterinar Science Technology. 5(5), 21-57.

Dustgani, A., Ebrahim, V. \& Mohammad, I. 2008. Preparation of chitosan nanoparticles ioded by dexamethasone phosphate. Iranian Journal of Pharmaceutical Sciences. 4(2), 111-114.

Hwang, J.K., Shim, J.S. \& Pyun, Y.R. 2000. Antibacterial Activity of xanthorrhizol from Curcuma xanthorrhiza against oral patogens. Fitoterapia. 71(3), 321-323.

Ilyina, A.V., Tikhonov, V.E., Albulov, A.I. \& Varlamov, V.P. 2000. Enzymic preparation of acid-free-water-soluble chitosan. Process Biochemistry, 35(6), 563-568.

Mat Zain, N., Stapley A.G.F. \& Shama, G. 2014. Green synthesis of silver and copper nanoparticles using ascorbic acid and chitosan for antimicrobial applications. Carbohydrate Polymers. 112(4), 195-202.

Monshi, A., Forouhu, M.R. \& Monshi, M.R. 2012. Modified scherrer equation to estimate more accurately nanocrystallite size using XRD. World Journal of Nano Science and Engineering. 2(3), 154-160.

Muljono, M. \& Patrick, S. 2016. Uji aktivitas antibakteri ekstrak daun mayana jantan (Coleus atropupureus Benth) terhadap pertumbuhan bakteri Streptococcus Sp. Dan Pseudomonas Sp. Jurnal eBiomedik. 4(1), 96-98.

Nguyen, N., Thi, Y., Nathaniel, G., Cheyann, L.W., Romeo, R. \& Huinan, L. 2018.
Antimicrobial activities and mechanisms of magnesium oxide nanoparticles $(\mathrm{nMgO})$ against pathogenic bacteria, yeasts, and biofilms. Scientific Reports. 8(1), 16260.

Praveenkumar K., Rabinal M.K., Kalasad M.N., Sankarappa T. \& Bedre, M.D. 2014, Chitosan capped silver nanoparticles used as pressure sensors, Journal Applied Physisc. 5(5), 43-51.

Rashada, M.M., Mohameda, R.M. \& El-Shall, H. 2008. Magnetic properties of nanocrystalline Sm-substituted $\mathrm{CoFe}_{2} \mathrm{O}_{4}$ synthesized by citrate precursor method. Journal of Materials Processing Technology. 198(1-3), 139-146.

Riyadh, K.D., Sayed, M., Khalil \& Ateyatallah, A. 2018. Chitosan- $\mathrm{MgO}$ nanocomposite: One pot preparation and its utility as an ecofriendly biocatalyst in the synthesis of thiazoles and $[1,3,4]$ thiadiazoles. Nanomaterials. 8(11), 928-930.

San, F.P., Zulkifli, M. \& Subaer. 2015. Sintesis dan karakterisasi struktur mikro komposit geopolimer nanopartikel $\mathrm{Fe}_{2} \mathrm{O}_{3}$. Prosiding Pertemuan Ilmiah. 25(2), 174-177.

Sun, L., Shao, R., Tang, L.Q. \& Zhidong, C. 2013. Syhntesis od $\mathrm{ZnFe}_{2} \mathrm{O}_{4} / \mathrm{ZnO}$ nanocomposites immobilized on graphene with enhanced photocatlytic akctivity under solar light irradition. Journal of Alloys and Compounds. 564(1), 55-62.

Xia, J., Xu, Y., Xu, H., Li, H. \& Liu, L. 2011. Enhanced photocatalytic activity of new photocatalyst $\mathrm{Ag} / \mathrm{AgCl} / \mathrm{ZnO}$. Journal of Alloys and Compounds. 509(7), 32863292.

Yang, G.J., Xie, F., Hong, Z. \& Cao, Y. 2012. Antimicrobial activity of silver nanoparticle impregnated bacterial cellulose membrane: Effect of fermentation carbon sources of bacterial cellulose. Carbohydrat Polymers. 87(1), 839-845.

Yiping, H., Shakuntala, I., Sue, R., Andrew, G., Terence P., Strobaugh, J.R. \& Peter, I. 2016. Study on the mechanism of antibacterial action of magnesium oxide nanoparticles against foodborne pathogens. Journal of Nanobiotechnology. 14(54), 1-9. 